\title{
АНАЛІЗ ЕКОНОМІКИ ПІДПРИЕМСТВА У СТАНІ НЕВИЗНАЧЕНОСТІ: ОСОБЛИВОСТІ ІНСТРУМЕНТАРІЮ ДОСЛІДЖЕННЯ
}

\author{
Ананьєва Олеся Олександрівна, \\ кандидат економічних наук, дочент, \\ ВН3 «Університет економіки та права «КРОК», \\ ORCID: https://orcid.org/0000-0002-9544-7408, \\ Гофман Мирослава Олександрівна, \\ кандидат економічних наук, дочент, \\ ВНЗ «Університет економіки та права «КРОК», \\ ORCID: https://orcid.org/0000-0002-3977-7584
}

Aнотація. Сучасні умови нестабільності економіки визначають особливі вимоги до забезпечення більшої економічної стійкості підприємств. Перший крок на цьому шляху - адекватний аналіз впливу економічної невизначеності на діяльність підприємств. Наука економічного аналізу має в своєму арсеналі сукупність традиційних та новітніх прийомів аналізу. Всі вони важливі для обгрунтування підприємницьких рішень. Але існуючі методики аналізу повинні постійно адаптуватися до нових економічних умов, включно з тими, що пов'язані з розширенням меж економічної невизначеності. Цей підрозділ монографії присвячено саме такій адаптації до потреб урахування в аналізі обставин невизначеності у діяльності підприємств.

Ключові слова: аналіз ефективності, збалансованість системи показників, експертний метод, статистичні методи економічного аналізу.

Проблема дослідження ризиків у діяльності підприємства, породжених економічною невизначеністю, перебуває у центрі уваги дослідників різних країн. Найбільш цитованими у цій царині є роботи Ф. Найта [1], Дж. Кальман [2], М. Круї, Д. Галай, Р. Марк [3], Т. Флін, М. Маккарті [4]. Досліджуючи невизначеність у діяльності підприємств, автори згаданих робіт роблять акценти на таких проблемах: трактування змісту та кількісного оцінювання ризиків, управління ризиками, контроль втрат проєктів, класифікація ризиків, метод передбачення ризиків.

Проблемі ідентифікації та оцінювання ризиків в українській економіці присвячено роботи багатьох українських дослідників. Особливе місце у цих дослідженнях належить українському науковцю та практику 3 української діаспори М. Паславському [5]. Згаданий дослідник дивився на ризики українського бізнесу з позицій глибокого знання української дійсності, поєднаного з розумінням загальних законів ведення бізнесу в розвинених країнах. 
Попри те, що на даний момент існує значна кількість наукових праць у галузі аналізу невизначеності (ризиків) у економічній діяльності підприємств, проблема адекватного (відповідного потребам) аналізу залишається актуальною.

Класифікуючи інструменти аналізу невизначеності, ми виокремлюємо, за різними класифікаційними ознаками, такі групи інструментів (рис. 1). Такими класифікаційними ознаками можуть бути: 1) частота (поширеність) використовуваних інструментів, що зазвичай пов'язано зі складністю їх застосування й тлумачення результатів: традиційні та новітні; 2) мета застосування інструментів аналізу невизначеності: для оцінювання внутрішніх та зовнішніх чинників впливу; 3) спрямованість аналізу, яка може орієнтуватися на оцінювання або майбутніх подій, або минулого: Ex post та Ex ante.

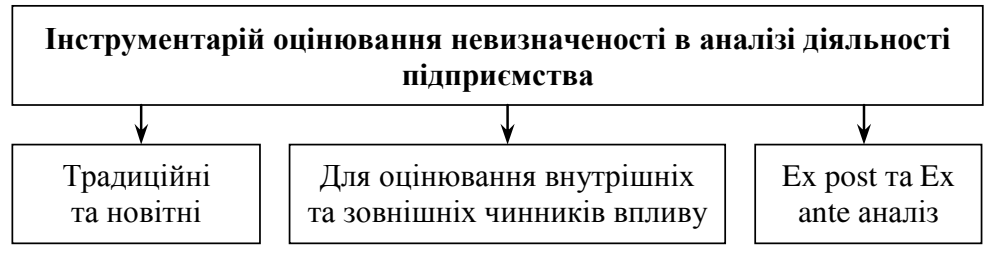

Рис. 1. Класифікація інструментів оцінювання невизначеності у діяльності підприємства

Джерело: складено авторами самостійно.

В оцінюванні невизначеності у діяльності підприємства, на наш погляд, найбільшої уваги потребує з'ясування особливостей традиційних та новітніх інструментів. Адже традиційні інструменти дають обмежену відповідь на питання, яким був або яким є вплив невизначеності. Натомість, новітні інструменти забезпечують більш глибокий аналіз невизначеності, але потребують більших за обсягом баз даних та складнішого інструментарію. Тому ми припускаємо, що традиційні й новітні інструменти мають використовуватися одночасно.

До традиційних інструментів оцінювання невизначеності, на наш погляд, належить іiі оцінювання через зміни у показниках ефективності підприємства, продуктивності праці тощо. Настання стрімких і непередбачуваних змін цих показників може інтерпретуватися як прояв невизначеності.

Категорія «ефективність» є багатогранною і має тривалу історію використання в науковому обігу. Майже в кожній науковій школі, починаючи з XVIII ст., намагалися дати іiі визначення. Вважається, що першими, хто спробували розкрити ії сутність, були В. Петті та Ф. Кене. Але вони розглядали ефективність як результативність і застосовували іï для оцінки окремих урядових чи приватних заходів [6]. Відносної 
самостійності ця категорія набула в роботах Д. Рікардо, який розглядав іiі як «відношення отриманого результату до певного виду витрат». Він здійснив спробу оцінити ефективність капіталу [7]. За уявленнями К. Маркса, виробництво $є$ ефективним, якщо при мінімальному авансованому капіталі створювати максимальну кількість продукту 3 можливими меншими витратами сил і засобів [8]. Представники неокласичної школи економіки XX ст. визначали ефективність як співвідношення результатів і витрат.

У всесвітньо відомому підручнику з економіки К. Макконел та С. Брю подано таке пояснення економічної ефективності: «Більша кількість продукту, отриманого від даного обсягу витрат, означає підвищення ефективності» [9].

Американський економіст $X$. Лібенштайн увів до наукового обігу поняття X-ефективність в економіці. Підприємство вважають $\mathrm{X}$-ефективним, якщо воно виробляє (реалізує) за наявних ресурсів $\mathrm{i}$ найкращою 3 доступних технологій максимально можливий обсяг продукції [10].

Дуже часто ефективність розглядають як результативність. У західних тлумачних словниках є смислова відмінність між поняттями ефективність та результативність. Зокрема, «еfficiency» перекладається 3 англійської як ефективність і означає - продуктивність, корисна робота [11]. Натомість, «Effectiveness», у перекладі 3 англійської, означає ступінь успішності, що дає бажаний результат [12]. Пітер Друкер також акцентував на цій відмінності понять, а саме «результативність» (effectiveness) означає «робити правильні речі» (doing the right things), a «ефективність» (efficiency) - «робити речі правильно» (doing thing sright). Він зазначає, що «для того, щоб бути успішною протягом тривалого часу, щоб вижити та досягнути своїх цілей, організація повинна бути як ефективною, так і результативною» [13].

Розмежування понять (явищ) «ефективність» та «результативність» затверджено в ДСТУ ISO 9000:2007 «Системи управління якістю: основні положення та словник термінів». Відповідно до даного стандарту ефективність (efficiency) - це співвідношення між досягнутим результатом і використаними ресурсами, а результативність (effectiveness) - це ступінь реалізації запланованої діяльності та досягнення запланованих результатів [14].

На нашу думку, ефективність діяльності підприємства - це його здатність досягати поставленої мети за умови наближення до оптимального співвідношення між отриманими результатами та затраченими на їх досягнення ресурсами.

3 огляду на таке наше уявлення про зміст поняття «ефективність діяльності підприємства» економічна невизначеність може подаватися як феномен, що може виявлятися у такому: 
- недосягненні визначеної мети або суттєвих відхиленнях від неї;

- зменшенні обсягів матеріальних та фінансових результатів діяльності підприємства;

- зростанні матеріальних та фінансових витрат на досягнення однакових, за інших рівних умов, тобто співставних, результатів.

При оцінюванні ефективності діяльності підприємства потрібно також враховувати різні підходи до визначення витрат, які можуть використовуватися при розрахунку ефективності:

1) ресурсний: результат порівнюється з ресурсами;

2) витратний: результат порівнюється з поточними витратами;

3) ресурсно-витратний: поєднання двох попередніх підходів.

Аналіз ефективності діяльності підприємства доцільно здійснювати за трьома групами показників: продуктивності, ефективності додаткових вкладень у капітал та рентабельності.

Показники продуктивності характеризують продуктивність ресурсів підприємства і показують, скільки гривень валової продукції припадає на одиницю (одну гривню вартості) ресурсів підприємства. Розраховується як відношення виробленої продукції до вартості окремих ресурсів.

У розвинених країнах продуктивність є предметом статистичних досліджень. У зарубіжній практиці найбільш поширеним показником продуктивності є показник продуктивності праці. Різниця лише в тому, що у країнах Східної Європи цей показник розраховують за випуском, а в західноєвропейських країнах, США та Австралії для розрахунку продуктивності праці використовують додану вартість. Показники продуктивності капіталу відносяться до показників національної статистики США і Австралії. Національна статистика зарубіжних країн розраховує та публікує показники як однофакторної, так i багатофакторної продуктивності. Багатофакторна продуктивність праці й капіталу (за випуском і доданою вартістю) широко розраховується в більшості країн з ринковою економікою. І лише в Канаді та США визначаються показники продуктивності всієї сукупності ресурсів (праці, основного й оборотного капіталу) [15].

Друга група показників - ефективності додаткових вкладень у капітал - використовується для визначення економічної доцільності додаткового нарощення капіталу. Відповідні показники розраховуються за формулою [16]:

$$
\text { Kef }=\frac{\operatorname{Prod}_{1}-\operatorname{Prod}_{0}}{C_{1}-C_{0}},
$$

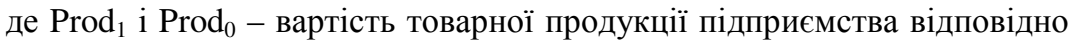
у звітному і базовому періодах; $C_{1}$ i $C_{0}$ - середньорічна вартість капіталу відповідно у звітному і базовому періодах. 
При розрахунку ефективності додаткового залучення джерел формування капіталу та додаткових вкладень в основний і оборотний капітал змінюється знаменник формули з урахуванням цих складових капіталу.

Слід зазначити, що економічна природа даного показника $\epsilon$ складною. При розрахунку цього показника можуть бути одержані чотири варіанти результатів:

$$
\begin{aligned}
& \text { 1. Kef }=\frac{\operatorname{Prod}_{1}-\operatorname{Prod}_{0}}{C_{1}-C_{0}}=\frac{\Delta \text { Prod }}{\Delta C}, \\
& \text { 2. Kef }=\frac{\operatorname{Prod}_{1}-\operatorname{Prod}_{0}}{C_{1}-C_{0}}=\frac{-\Delta \text { Prod }}{\Delta C}, \\
& \text { 3. Kef }=\frac{\operatorname{Prod}_{1}-\operatorname{Prod}_{0}}{C_{1}-C_{0}}=\frac{\Delta \text { Prod }}{-\Delta C}, \\
& \text { 4. Kef }=\frac{\operatorname{Prod}_{1}-\operatorname{Prod}_{0}}{C_{1}-C_{0}}=\frac{-\Delta \text { Prod }}{-\Delta C} \text {. }
\end{aligned}
$$

Перший варіант показує, що із зростанням розміру капіталу підприємства зростає і товарна продукція. За таких умов важливо, щоб даний показник мав значення більше одиниці, що свідчитиме про високу ефективність додаткових вкладень у капітал. У другому варіанті результат буде зі знаком мінус, оскільки зростання капіталу супроводжується зменшенням товарної продукції, що характеризує неефективні додаткові вкладання коштів у капітал. При цьому важливо мінімізувати негативні наслідки, тому значення даного показника має наближатися до 0. Третій варіант відображає ситуацію, коли приріст продукції одержують при зменшенні величини капіталу. Результат також буде зі знаком мінус. Зростання значення даного показника за модулем свідчить про підвищення ефективності використання капіталу. При цьому потрібно пам'ятати, що такий варіант не $є$ прийнятним для підприємств, які мають недостатню забезпеченість капіталом. I останній, четвертий, варіант одержують за умови, коли зменшення розміру капіталу призводить до зменшення товарної продукції. Найменш несприятливою ситуацією $є$ така, коли результат був меншим одиниці, оскільки за таких умов товарна продукція зменшується не так істотно, як капітал підприємства.

Важливе значення для аналізу підприємства мають показники рентабельності. Вони відображають рівень прибутковості підприємства, а також можливості формування засобів для здійснення поточної діяльності підприємства.

На рис. 2. представлено основні показники аналізу економіки підприємства за кожною із трьох розглянутих груп. 


\begin{tabular}{|c|c|c|}
\hline \multicolumn{3}{|c|}{ Показники аналізу економіки підприсмства } \\
\hline$\downarrow$ & $\downarrow$ & $\downarrow$ \\
\hline $\begin{array}{c}\text { Показники } \\
\text { продуктивності } \\
\text { - продуктивність праці; } \\
\text { - продуктивність } \\
\text { капіталу; } \\
\text { - фондовіддача; } \\
\text { - продуктивність } \\
\text { оборотного капіталу; } \\
\text { - продуктивність } \\
\text { власного капіталу; } \\
\text { - продуктивність } \\
\text { позичкового капіталу. }\end{array}$ & $\begin{array}{c}\text { Показники } \\
\text { ефективності } \\
\text { додаткових вкладень у } \\
\text { капітал } \\
\text { - ефективність додаткових } \\
\text { вкладень у капітал; } \\
\text { - ефективність додаткових } \\
\text { вкладень в основний } \\
\text { капітал; } \\
\text { - ефективність додаткових } \\
\text { вкладень в оборотний } \\
\text { капітал. }\end{array}$ & $\begin{array}{c}\text { Показники } \\
\text { рентабельності } \\
\text { - рентабельність продукції; } \\
\text { - рентабельність продажу; } \\
\text { - рентабельність капіталу; } \\
\text { - рентабельність основного } \\
\text { капіталу; } \\
\text { - рентабельність оборотного } \\
\text { капіталу; } \\
\text { - рентабельність власного } \\
\text { капіталу. }\end{array}$ \\
\hline
\end{tabular}

\section{Рис. 2 Основні показники аналізу економіки підприємства} Джерело: складено авторами самостійно.

Для поглибленого аналізу ефективності використання капіталу застосовують багатофакторну модель, що була розроблена фірмою «Дюпон» у 20-х роках минулого століття. Вона передбачає розкладання рентабельності капіталу на окремі показники, пов'язані в єдиній системі. Кожен з факторів $є$ змістовним фінансовим показником. Такий аналіз дає можливість визначити індивідуальний вплив кожного фактору на результати господарювання, своєчасно виявляти й усувати їх негативну дію. Крім того, завдяки відповідним розрахункам оцінюють невикористані внутрішні резерви щодо підвищення ефективності діяльності підприємств. Рентабельність капіталу (ROC) за даною моделлю визначається такою формулою [17]:

$$
\begin{aligned}
& R O C=R O S \times K O C, \\
& \frac{P}{C}=\frac{P}{S A L} \times \frac{S A L}{C},
\end{aligned}
$$

де $R O S$ - рентабельність продажу; Кос - коєфіцієнт обороту капіталу; $P$ - операційний прибуток підприємства; $S A L$ - виручка від реалізації продукції.

Згадана модель показує вплив на рентабельність капіталу рентабельності продажу та коєфіцієнту обороту капіталу. Аналізуючи показники, можна визначити резерви подальшого підвищення ефективності використання капіталу. Причинами зниження рентабельності капіталу можуть бути як зниження рентабельності продажу, так і уповільнення обороту капіталу. Якщо на зниження показника рентабельності більшою мірою впливає перший фактор, то необхідно більше уваги приділяти маркетингу, ціновій та асортиментній політиці. Зростання даного 
показника може відбуватися під впливом як внутрішніх, так і зовнішніх факторів, на які підприємство не може впливати. Тому, аналізуючи показник, необхідно враховувати вплив усіх можливих факторів. Прискорення обороту капіталу можна досягти шляхом зменшення основного чи оборотного капіталу. Тоді увагу необхідно зосереджувати на продажу чи списанні основних засобів, що не використовуються чи неефективно використовуються; зменшенні запасів сировини, матеріалів, незавершеного виробництва, готової продукції; зменшенні дебіторської заборгованості.

Згадана модель $є$ спрощеною, але їі можна переформувати у багатофакторну модель, яка дасть змогу повною мірою визначити вплив окремих факторів на ефективність використання капіталу підприємств. Багатофакторну модель ефективності використання капіталу можна, на наш погляд, представити таким чином [18]:

$$
\begin{aligned}
& R O C=R O S \times C P \times K r \times K d \times K f l \times K e, \\
& \frac{P}{C}=\frac{P}{S A L} \times \frac{S A L}{F C} \times \frac{F C}{W C} \times \frac{W C}{D} \times \frac{D}{E} \times \frac{E}{C},
\end{aligned}
$$

де $R O C$ - рентабельність капіталу; $P$ - операційний прибуток підприємства, тис. грн; $C$ - вартість усього капіталу, тис. грн; $S A L$ - виручка від реалізації продукції, тис. грн; $F C$ - вартість основного капіталу, тис. грн; $W C$ - вартість оборотного капіталу, тис. грн; $D$ - позичковий капітал, тис. грн; $E$ - власний капітал, тис. грн.

Відповідно до запропонованої моделі, на рентабельність капіталу впливають такі фактори: рентабельність продажу $(R O S)$, продуктивність основного капіталу $(P C)$, коєфіцієнт співвідношення основного й оборотного капіталу $(\mathrm{Kr})$, коєфіцієнт покриття позичкового капіталу оборотним $(K d)$, коєфіцієнт фінансового лівериджу $(K f l)$, коєфіцієнт автономії $(K e)$.

Для визначення впливу окремих факторів на рентабельність капіталу пропонуємо такий алгоритм обчислень, що базується на використанні індексного (Ir) методу дослідження:

$$
\begin{aligned}
& I r=\frac{R O S_{1} \times P C_{1} \times K r_{1} \times K d_{1} \times K f l_{1} \times K e_{1}}{R O S_{0} \times P C_{0} \times K r_{0} \times K d_{0} \times K f l_{0} \times K e_{0}}=\frac{R O S_{1} \times P C_{0} \times K r_{0} \times K d_{0} \times K f l_{0} \times K e_{0}}{R O S_{0} \times P C_{0} \times K r_{0} \times K d_{0} \times K l_{0} \times K e_{0}} \times \\
& \times \frac{R O S_{1} \times P C_{1} \times K r_{0} \times K d_{0} \times K f l_{0} \times K e_{0}}{R O S_{1} \times P C_{0} \times K r_{0} \times K d_{0} \times K f l_{0} \times K e_{0}} \times \frac{R O S_{1} \times P C_{1} \times K r_{1} \times K d_{0} \times K f l_{0} \times K e_{0}}{R O S_{1} \times P C_{1} \times K r_{0} \times K d_{0} \times K l_{0} \times K e_{0}} \times \\
& \times \frac{R O S_{1} \times P C_{1} \times K r_{1} \times K d_{1} \times K f l_{0} \times K e_{0}}{R O S_{1} \times P C_{1} \times K r_{1} \times K d_{0} \times K l_{0} \times K e_{0}} \times \frac{R O S_{1} \times P C_{1} \times K r_{1} \times K d_{1} \times K l_{1} \times K e_{0}}{R O S \times P C_{1} \times K r_{1} \times K d_{1} \times K f l_{0} \times K e_{0}} \times \\
& \times \frac{R O S_{1} \times P C_{1} \times K r_{1} \times K d_{1} \times K f l_{1} \times K e_{1}}{R O S_{1} \times P C_{1} \times K r_{1} \times K d_{1} \times K f l_{1} \times K e_{0}} .
\end{aligned}
$$


Перший частковий індекс відображає вплив рентабельності продажу на рентабельність капіталу, другий - продуктивності основного капіталу, третій - коєфіцієнта співвідношення між основним і оборотним капіталом, четвертий - коєфіцієнта покриття позичкового капіталу оборотним, п’ятий - коєфіцієнта фінансового лівериджу, шостий коєфіцієнта автономії.

За моделлю Дюпон також можна визначати вплив окремих факторів на рентабельність власного капіталу [19]:

$$
\begin{aligned}
& R O E=R O S \times K o c \times K d ; \\
& \frac{N P}{E}=\frac{N P}{S A L} \times \frac{S A L}{C} \times \frac{C}{E} ;
\end{aligned}
$$

де $R O E$ - рентабельність власного капіталу; $K d$ - коєфіцієнт боргового навантаження; $N p$ - чистий прибуток підприємства.

На рентабельність власного капіталу, за цією моделлю, впливає три фактори: рентабельність продажу $(R O S)$; коєфіцієнт обороту капіталу $(K o c)$; коєфіцієнт боргового навантаження $(K d)$. Специфіку впливу перших двох факторів розглянуто при аналізі рентабельності всього капіталу підприємства. Коєфіцієнт боргового навантаження відображає обрану підприємством фінансову структуру капіталу. Його зростання, з одного боку, може підвищувати рентабельність власного капіталу, а з іншого збільшувати ризик банкрутства підприємства.

Зростання невизначеності зазвичай пов'язується 3 погіршенням ситуації у провідних галузях національних економік. Українська економіка була й ще залишається індустріально-аграрною. Тому динаміка промислового виробництва у ній $є$ вирішальним маркером змін. Для кожного окремого українського підприємства динаміка промислового виробництва може розглядатися як зовнішній чинник визначеності або, навпаки, невизначеності стану. Поточний стан української промисловості не відповідає вимогам, що диктуються умовами глобальних змін. Промислове виробництво перестало бути основним чинником зростання національної економіки.

Падіння промислового виробництва загалом, а особливо виробництва інвестиційної продукції, спричинює негативні наслідки відставання і послаблення національної економіки, втрату конкурентних позицій України на світових ринках. Непоправних втрат зазнала Україна та її промисловий потенціал унаслідок воєнної агресії східного сусіда, окупації й анексії промислово інтенсивних регіонів Донбасу та Криму, розграбування майна підприємств, згортання виробництва на непідконтрольних українській владі й прилеглих до них територіях. Ведення торговельної війни проти українського експорту призвело до руйнування промислових потужностей, розриву традиційних внутрішніх 
і зовнішніх господарських зв'язків, обвального скорочення масштабів виробництва.

Розширення зв'язків $з$ європейськими партнерами чинить вагомий позитивний вплив на розвиток промислового потенціалу країни. Цьому сприяє дія Угоди про асоціацію між Україною та СС, особливо, існування зони вільної торгівлі. Українські експортери частково компенсували втрату ринків колишнього партнера завдяки активізації торговельних відносин з СС, який став для України основним торговим партнером $\mathrm{i}$ ключовим іноземним інвестором [20].

Показники аналізу економіки підприємств за кожною із трьох запропонованих нами груп на основі даних промислових підприємств України подано в табл. 1.

Табличя 1

Основні показники продуктивності промислових підприємств України за 2013 - 2018 рр.

\begin{tabular}{|l|c|c|c|c|c|c|c|}
\hline $\begin{array}{c}\text { Показники } \\
\text { продуктивності }\end{array}$ & $\mathbf{2 0 1 3}$ р. & $\mathbf{2 0 1 4}$ p. & $\mathbf{2 0 1 5}$ р. & $\mathbf{2 0 1 6}$ p. & $\mathbf{2 0 1 7}$ p. & $\mathbf{2 0 1 8}$ р. & $\begin{array}{c}\text { Відносне } \\
\text { відхилення } \\
\mathbf{2 0 1 8} \text { р. до } \\
\mathbf{2 0 1 3} \text { р. . \% }\end{array}$ \\
\hline $\begin{array}{l}\text { Продуктивність } \\
\text { праці, тис. грн /особу }\end{array}$ & 418,64 & 532,19 & 694,05 & 851,74 & 1097,38 & 1255,76 & 299,96 \\
\hline $\begin{array}{l}\text { Продуктивність } \\
\text { капіталу }\end{array}$ & 0,70 & 0,69 & 0,73 & 0,75 & 0,84 & 0,91 & 129,87 \\
\hline Фондовіддача & 0,75 & 0,72 & 0,56 & 0,56 & 0,89 & 0,98 & 129,57 \\
\hline $\begin{array}{l}\text { Продуктивність } \\
\text { оборотного капіталу }\end{array}$ & 1,56 & 1,51 & 1,51 & 1,44 & 1,51 & 1,67 & 107,53 \\
\hline $\begin{array}{l}\text { Продуктивність } \\
\text { власного капіталу }\end{array}$ & 1,80 & 2,05 & 3,04 & 3,82 & 4,57 & 4,17 & 231,36 \\
\hline $\begin{array}{l}\text { Продуктивність } \\
\text { позичкового капіталу }\end{array}$ & 1,14 & 1,04 & 0,96 & 0,93 & 1,02 & 1,16 & 101,64 \\
\hline
\end{tabular}

Джерело: розраховано авторами за даними Державної служби статистики України.

Аналізуючи дані табл. 1, можна констатувати, що за період 2013 2018 рр. показник продуктивності праці на промислових підприємствах в Україні має стійку тенденцію до зростання. Середній річний приріст показника складає 167,4 тис. грн на одного зайнятого. У 2018 р. цей показник збільшився у майже 3 рази порівняно з 2013 р. Проте варто зазначити, що Україна за показником продуктивності праці в промисловості відстає від західноєвропейських країн. Основними причинами низької продуктивності праці є:

- зношені і застарілі основні фонди;

- застарілі технології;

- недостатньо ефективна організація операційних систем та виробничих процесів;

- неефективна організація праці; 
- низькоефективний менеджмент;

- практична відсутність стимулів до побудови інноваційного виробництва, пов' язана з високим рівнем монополізації;

- слабка інвестиційна інфраструктура;

- недостатня інформатизація та автоматизація виробництва.

Показник продуктивності капіталу виявляє ефективність використання капіталу і має тенденцію до зростання протягом 2013 2018 рр., що є позитивним. Проте, дані табл. 1 свідчать про низький рівень продуктивності капіталу. Так, на кожну гривню, вкладену у виробництво продукції у 2013 р., було отримано всього 70 коп. виробленої продукції, в 2017 р. - 84 коп., а в 2018 р. - 91 коп.

Позитивним для промислових підприємств України є збільшення показника фондовіддачі в динаміці. Як видно 3 табл. 1, показник фондовіддачі зменшився в 2015 р. в порівнянні з 2014 р. на 22,22\%. На рівень фондовіддачі впливають різні фактори, такі як зміна обсягу продукції, ефективність використання основних засобів. Зростання даного показника спостерігається в 2017 р. й становить 0,89. У 2018 р. він збільшився відносно 2013 р. на 29,57\%.

Коєфіцієнт продуктивності оборотного капіталу характеризує ефективність використання оборотного капіталу підприємства. Від якості управління оборотним капіталом залежить безперервність процесу виробництва та реалізації продукції, а як наслідок, - його платоспроможність та рентабельність. Ефективність використання оборотного капіталу полягає в тому, щоб на кожну одиницю оборотного капіталу досягати максимум збільшення виробництва. Для досліджуваного періоду прослідковується тенденція незначної зміни даного показника. Так, показник продуктивності оборотного капіталу в 2018 р. збільшився лише на 7, 53\% відносно 2013 р.

Щодо показника продуктивності власного капіталу, то тут спостерігається тенденція до його зростання протягом досліджуваного періоду, що є позитивним для промислових підприємств. Так, продуктивність власного капіталу в 2018 р. зросла в 2,31 рази, на відміну від 2013 р. Досягнути таких результатів вдалося за рахунок збільшення обсягів виготовленої продукції.

Залучення позикових коштів до обороту підприємства $є$ нормальним явищем. За рахунок такого залучення підприємство покращує свій фінансовий стан, щоправда, за умови своєчасного повернення боргів. Показник продуктивності позичкового капіталу демонструє ефективність використання позичкового капіталу. Дані таблиці свідчать про зменшення даного показника протягом 2014 - 2016 pp., і лише в 2017 р. він збільшився порівняно з 2016 р. на 9,68\%. Можна зробити висновок про неефективне використання позичкового капіталу. 
Загалом усі аналізовані показники зростають, що $є$ досить позитивним для промисловості. Для детальнішого аналізу перейдемо до показників ефективності додаткових вкладень у капітал (табл. 2).

Табличя 2

\section{Показники ефективності додаткових вкладень у капітал} промислових підприсмств України за 2014 - 2018 рр.

\begin{tabular}{|l|c|c|c|c|c|}
\hline \multicolumn{1}{|c|}{$\begin{array}{c}\text { Показники ефективності } \\
\text { додаткових вкладень у капітал }\end{array}$} & $\mathbf{2 0 1 4}$ p. & $\mathbf{2 0 1 5}$ p. & $\mathbf{2 0 1 6}$ p. & $\mathbf{2 0 1 7}$ p. & $\mathbf{2 0 1 8}$ p. \\
\hline $\begin{array}{l}\text { Ефективність додаткових вкладень у } \\
\text { капітал }\end{array}$ & 0,547 & 1,047 & 0,841 & 1,445 & 2,463 \\
\hline $\begin{array}{l}\text { Ефективність додаткових вкладень в } \\
\text { основний капітал }\end{array}$ & 0,419 & 0,260 & 0,553 & $-0,781$ & 3,375 \\
\hline $\begin{array}{l}\text { Ефективність додаткових вкладень в } \\
\text { оборотний капітал }\end{array}$ & 0,964 & 1,501 & 1,160 & 1,870 & 7,432 \\
\hline $\begin{array}{l}\text { Ефективність додаткових вкладень у } \\
\text { власний капітал }\end{array}$ & $-1,384$ & $-2,250$ & $-11,999$ & 15,397 & 2,539 \\
\hline $\begin{array}{l}\text { Ефективність додаткових вкладень у } \\
\text { позичковий капітал }\end{array}$ & 0,392 & 0,714 & 0,786 & 1,594 & 82,279 \\
\hline
\end{tabular}

Джерело: розраховано авторами за даними Державної служби статистики Украӥни.

Показник ефективності додаткових вкладень у капітал показує, що із збільшенням розміру капіталу підприємств промисловості у 2017 2018 рр. зріс і обсяг виробленої продукції. Проте, аналіз даних табл. 2 демонструє низьку ефективність додаткових вкладень коштів у капітал у 2014 та 2016 рр., оскільки темпи зростання обсягів виробництва продукції були нижчими за темпи зростання вартості капіталу.

Негативна тенденція спостерігається щодо показника ефективності додаткових вкладень в основний капітал. Так, значення даного показника знаходиться на рівні менше одиниці, що свідчить про високу неефективність додаткових вкладень в основний капітал. I лише в 2018 році спостерігається результат ефективності таких додаткових вкладів.

Коєфіцієнти ефективності додаткових вкладень у власний капітал мали від'ємне значення в 2014 - 2016 рр., що характеризує неефективні додаткові вкладення коштів у власний капітал. Цей показник відображає ситуацію, коли приріст виробленої продукції було отримано за рахунок зменшення власного капіталу. Результати даного показника за модулем зростають, а починаючи з 2017 р., зростає його абсолютне значення. Але варто пам'ятати про забезпеченість підприємства капіталом.

Аналізуючи показник ефективності додаткових вкладень у позичковий капітал, прослідковується тенденція до зростання показника. Це свідчить про зростання розміру позичкового капіталу та обсягу виробленої продукції. Висока ефективність додаткових залучень позичкового капіталу спостерігається у 2018 році. 
Третя група показників оцінювання ефективності діяльності підприємств промисловості подана в табл. 3.

Таблиия 3

Оцінка показників рентабельності промислових підприємств України за 2013 - 2018 рр.

\begin{tabular}{|l|c|c|c|c|c|}
\hline \multicolumn{1}{|c|}{ Показники рентабельності } & $\mathbf{2 0 1 4}$ p. & $\mathbf{2 0 1 5}$ p. & $\mathbf{2 0 1 6}$ p. & $\mathbf{2 0 1 7}$ p. & $\mathbf{2 0 1 8}$ p. \\
\hline Рентабельність продукції, \% & $-87,39$ & 24,09 & 24,52 & 25,91 & 24,27 \\
\hline $\begin{array}{l}\text { Рентабельність продажу за чистим } \\
\text { прибутком, \% }\end{array}$ & $-114,01$ & $-9,82$ & $-1,06$ & 1,96 & 3,31 \\
\hline $\begin{array}{l}\text { Рентабельність капіталу за чистим } \\
\text { прибутком, \% }\end{array}$ & $-9,23$ & $-8,57$ & $-0,96$ & 1,91 & 3,55 \\
\hline Рентабельність власного капіталу, \% & $-27,49$ & $-35,58$ & $-4,92$ & 10,43 & 16,31 \\
\hline Рентабельність позичкового капіталу, \% & $-13,91$ & $-11,30$ & $-1,20$ & 2,33 & 4,54 \\
\hline
\end{tabular}

Джерело: розраховано авторами за даними Державної служби статистики України.

Показник рентабельності продукції відображає одержуваний підприємством прибуток з кожної гривні, вкладеної у виробництво. У результаті аналізу цих показників та їх динаміки варто констатувати, що для досліджуваного періоду рівень рентабельності продукції достатньо низький, що визначено високою собівартістю. Цей показник майже не змінювався протягом $2015-2018$ рр.

Рентабельність продажу характеризує ефективність здійснення процесів реалізації готової продукції промислових підприємств. Дані таблиці свідчать про збитковість продажу промислової продукції протягом періоду з 2014 р. по 2016 р. Починаючи лише з 2017 р., рентабельність продажу промислової продукції характеризується позитивним значенням показника. У 2018 р. показник рентабельності продажу суттєво підвищився порівняно з 2014 р. і становить 3,31\%.

Показник рентабельності капіталу за чистим прибутком показує величину чистого прибутку, що припадає на одну гривню капіталу. Ці показники були розраховані із застосуванням чистого прибутку i протягом періоду з 2014 р. по 2016 р. мають від'ємне значення, оскільки результатом діяльності суб'єктів господарювання у промисловості є збиток. Позитивне значення показника чистого прибутку спостерігається, починаючи з 2017 р. Так, у 2017 році на одну гривню капіталу припадає лише 0,019 грн чистого прибутку та 2018 р. - 0,035 грн.

Показник рентабельності власного капіталу займає особливе місце серед показників рентабельності й показує ефективність використання власних коштів підприємства. Значення цього показника відображає ступінь привабливості підприємства для вкладення коштів інвесторів. Для досліджуваного періоду рівень рентабельності власного 
капіталу дуже низький, у 2018 р. на одну гривню власного капіталу припадало близько 0,16 грн чистого прибутку, і це найвищий рівень показника. Рівень рентабельності власного капіталу в промисловості можна підвищити за рахунок зусиль управлінського персоналу.

Аналогічна тенденція спостерігається і при аналізі показника рентабельності позичкового капіталу. Позитивне значення показника спостерігається в 2017 р. й на одну гривню позичкового капіталу припадає лише 0,02 грн прибутку та 2018 р. - 0,04 грн.

Отже, як випливає з проведеного аналізу, особливо складною була ситуація на промислових підприємствах України у 2014 р. у зв’язку з військовою агресією Росії.

Наш детальний аналіз традиційних і більш оновлених показників ефективності діяльності підприємства у різних їі проявах для оцінювання невизначеності є важливим, тому що дає можливість з'ясувати таке. Маючи достатню базу даних за різними показниками ефективності можемо скомпонувати вимірник оцінювання відхилень, наприклад, за дисперсією або за так званими gaps (розривами). Тоді мінімізація відхилень може бути потрактована як зменшення невизначеності, натомість, збільшення відхилень за певний період - як збільшення невизначеності. До прикладу, якщо йдеться про оцінювання невизначеності за показником рентабельності, то логіка оцінювання невизначеності з використанням цього традиційного показника 3 арсеналу інструментів аналізу могла б виглядати так:

$$
\sum_{i=1}^{n} \operatorname{gaps}\left(\operatorname{Prof}_{i}^{*}-\operatorname{Prof}_{\text {trend }}^{*}\right) \rightarrow 0,
$$

де $\left(\operatorname{Prof}_{i}^{*}-\operatorname{Prof}_{\text {trend }}^{*}\right)$ - відхилення фактичного значення рентабельності у конкретному році від значень тренду.

Для оцінювання ефективності підприємств в умовах невизначеності 3 урахуванням впливів конкурентного національного та глобального середовища доцільно використовувати показник EVA (Economic Value Added) - економічна додана вартість та збалансовану систему інших показників.

Модель «Економічної доданої вартості» (EVA) була розроблена Б. Стюартом і Д. Стерном та зареєстрована компанією «Stern Stewart \& Co» на початку 90-х років XX століття. Дана модель використовується такими відомими компаніями, як: «Coca-Cola», «Siemens», «IBM». На відміну від традиційних показників ефективності, показник EVA відображає тісний зв'язок з вартістю акцій і враховує фактор ризику. Даний показник дозволяє оцінити ефективність діяльності підприємства 3 позиції перетворення прибутку в його ринкову вартість [21]. 
Показник економічної доданої вартості за змістом $є$ економічним прибутком, який враховує не лише бухгалтерські витрати, але й альтернативні витрати інвестованого капіталу. Тобто, при розрахунку показника EVA із суми прибутку віднімаються не тільки витрати на залучення позичкового капіталу, а й витрати на власний капітал.

Показник EVA можна застосовувати для оцінки ефективності діяльності як підприємства загалом, так і його окремих структурних підрозділів. Його також використовують для оцінювання результатів діяльності менеджерів та їх винагородження.

Для розрахунку показника «Економічна додана вартість» використовують таку базову формулу [22]:

$$
E V A=N O P A T-(W A C C \times I C),
$$

де NOPAT - чистий операційний прибуток після оподаткування; WACC середньозважена вартість капіталу; $I C$ - інвестований капітал.

Середньозважена вартість капіталу визначається за формулою:

$$
W A C C=\frac{E}{C} \times r_{e}+\frac{D}{C} \times r_{d} \times(1-t),
$$

де $E$ - власний капітал підприємства; $C$ - загальний розмір капіталу підприємства; $D$ - позичковий капітал підприємства; $r_{e}$ i $r_{d}-$ відповідно вартість власного і позичкового капіталу, $\$ ; t$ - ставка податку на прибуток.

Для розрахунку EVA розробники внесли близько 160 поправок до статей балансу і звіту про фінансові результати, але в кожному конкретному випадку використовуються лише окремі поправки. Зокрема, поправки стосуються визначення інвестованого капіталу. Так, до останнього необхідно включати інвестиції в рекламу, навчання персоналу, дослідження та розробки, реструктуризацію бізнесу. Також складнощі у розрахунку даного показники зумовлені необхідністю визначення додаткових даних при розрахунку середньозваженої вартості капіталу, яких немає у фінансовій звітності.

Результати розрахунку економічної доданої вартості можна інтерпретувати таким чином:

- $E V A=0$. Ринкова вартість підприємства дорівнює балансовій вартості чистих активів. У власників у такому випадку немає значної зацікавленості в інвестуванні капіталу в підприємство. Прибутковість інвестування в підприємство прирівнюється до прибутковості вкладень у банківські депозити.

- EVA > 0. Ринкова вартість підприємства перевищує балансову вартість чистих активів. Висока ефективність інвестицій у підприємство і стимулює подальші вкладення капіталу власником у підприємство. 
- $E V A<0$. Ринкова вартість підприємства $є$ меншою за балансову вартість чистих активів. Власники починають втрачати інвестований у підприємство капітал. Подальші інвестиції в підприємство $є$ неефективними [23].

Загалом, застосування показника економічної доданої вартості в аналізі економіки підприємства $є$ дуже перспективним. Він дозволяє більш об'єктивно оцінити результати діяльності підприємства, порівняно 3 показником чистого прибутку. Але його застосування на вітчизняних підприємствах потребує здійснення певних змін організаційного, інформаційного, кадрового характеру. Зокрема, налагодження на підприємстві якісного ведення управлінського обліку, підготовки персоналу до впровадження відповідної моделі управління.

Потрібно також враховувати, що показник економічної доданої вартості оцінює ефективність діяльності підприємства 3 погляду його власників. Але на діяльність підприємства здійснюють вплив й інші зацікавлені особи, зокрема, персонал, менеджери, покупці, кредитори, держава. Їхні інтереси при застосуванні лише показника EVA можуть бути не враховані, що зумовлюватиме зниження вартості підприємства. За таких умов доречним $€$ поєднання використання моделі економічної доданої вартості із збалансованою системою показників. Зокрема, показник $E V A$ доцільно використовувати як один із базових показників оцінки у перспективі «Фінанси».

Збалансована система показників (ЗСП) - це новий підхід в управлінні ефективністю та аналізі суб'єктів господарювання. Вона була розроблена Р. Капланом, професором розвитку лідерства в Гарвардській школі бізнесу, та Д. Нортоном, засновником і президентом Balansed Scorecard Collaborative Inc. Методика Balansed Scorecard застосовується на підприємствах 3 метою підвищення ефективності управління за рахунок оптимального набору індикаторів діяльності. Особливістю застосування системи збалансованих показників є те, що вона складається $з$ чотирьох перспектив, за якими проводять аналіз ефективності діяльності підприємства:

- навчання та перспективи зростання (The Learning and Growth perspective);

- внутрішньофірмові процеси, внутрішні бізнес-процеси (Тhe Business Process Perspective);

- орієнтація на споживача, споживчий аспект (The Customer Perspective);

- фінансова перспектива (The Financial Perspective).

Перевагами збалансованої системи показників $є$ те, що вона включає не лише фінансові показники, а й нефінансові.

Алгоритм побудови збалансованої системи показників подано на рис. 3. 


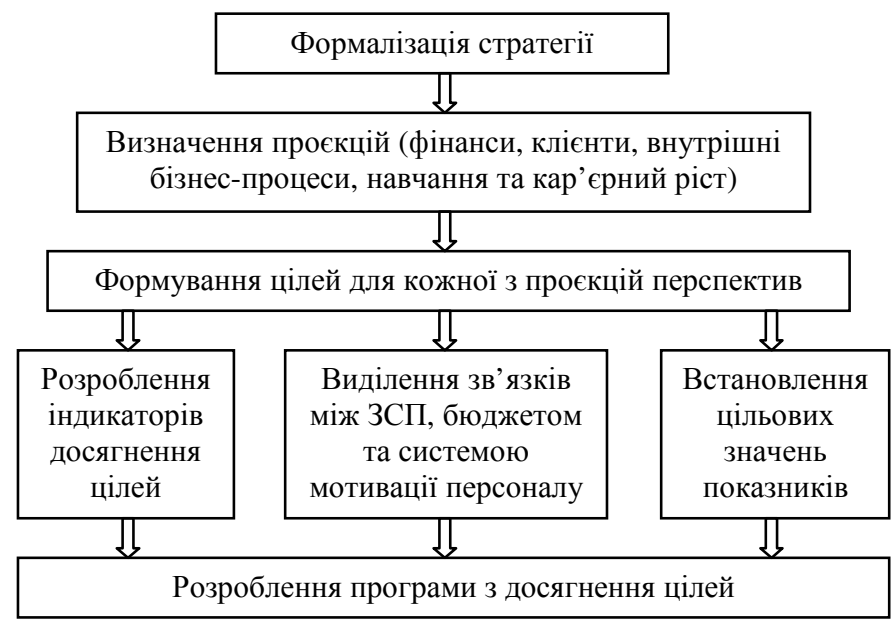

Рис. 3. Алгоритм розроблення збалансованої системи показників Джерело: складено авторами на основі [24].

На практиці підприємства обирають ті показники, які найбільше відповідають його стратегічній меті. Також підприємства можуть додавати п'ятий вектор до чотирьох перерахованих вище або замінювати на той, який найкраще зможе відобразити стратегію конкретного підприємства.

Як ми бачимо, специфіка збалансованої системи показників полягає в тому, що немає єдиного універсального переліку показників, які можна було б використати для аналізу діяльності того чи того підприємства. Вони формуються індивідуально для кожного підприємства, виходячи 3 його цілей. Тому на рис. 4 нами запропоновано перелік показників за кожною із чотирьох перспектив, які можна використовувати промисловим підприємствам при побудові збалансованої системи показників.

Практична цінність збалансованої системи показників полягає у вирішенні проблеми досягнення стратегічних цілей, що $є$ важливим для будь-яких підприємств, незалежно від галузі функціонування. Оптимальний набір показників, які кожне підприємство може обрати самостійно відповідно до своєї стратегічної мети, підвищить цінність прогнозної інформації для управління. Він дозволить оперативно коригувати управлінські рішення; дасть змогу за допомогою нефінансових показників оцінювати ефективність діяльності підприємства, його конкурентоспроможність; зробить діяльність українських підприємств більш прозорою для можливих інвесторів. 


\begin{tabular}{|c|c|c|c|}
\hline & алансована систе & показників & \\
\hline $\begin{array}{c}\text { Фінансова } \\
\text { перспектива } \\
\text { - економічна додана } \\
\text { вартість (ЕVА); } \\
\text { - чистий прибуток; } \\
\text { - показники } \\
\text { рентабельності; } \\
\text { - коєфіцієнти } \\
\text { ліквідності та } \\
\text { платоспроможності; } \\
\text { - показники } \\
\text { фінансової } \\
\text { стійкості. }\end{array}$ & $\begin{array}{c}\text { Внутрішні } \\
\text { бізнес-процеси } \\
\text { - частка інноваційної } \\
\text { продукції; } \\
\text { - тривалість } \\
\text { виробничого циклу; } \\
\text { - затримка в } \\
\text { постачанні } \\
\text { підприємства } \\
\text { матеріалами; } \\
\text { - витрати за } \\
\text { основними бізнес- } \\
\text { процесами; } \\
\text { - частка бракованої } \\
\text { продукції. }\end{array}$ & \begin{tabular}{|} 
Споживча \\
перспектива \\
- частка ринку; \\
- лояльність \\
клієнтів; \\
- рівень \\
відпускних \\
цін; \\
- кількість \\
рекламацій; \\
- темпи \\
зростання \\
ринку.
\end{tabular} & $\begin{array}{c}\text { Перспектива } \\
\text { навчання та } \\
\text { зростання персоналу } \\
\text { - ступінь } \\
\text { задоволення } \\
\text { працівників; } \\
\text { - плинність } \\
\text { персоналу; } \\
\text { - продуктивність } \\
\text { праці; } \\
\text { - коєфіцієнт } \\
\text { підвищення } \\
\text { кваліфікації; } \\
\text { - видані винагороди } \\
\text { та премії. }\end{array}$ \\
\hline
\end{tabular}

Рис. 4. Показники, які можуть бути використані при побудові ЗСП для промислових підприємств

Джерело: складено авторами самостійно.

До важливих інструментів оцінювання невизначеності діяльності підприємства слід віднести методи ідентифікації ризиків. Сучасні методи оцінки ризиків варто поділити на дві групи: якісні та кількісні.

Якісні методи використовуються на початковому етапі аналізу. Їх основною задачею $\epsilon$ виявлення основних ризиків, які виникають у процесі фінансово-господарської діяльності підприємства. Більшість науковців відзначають складність застосування якісних методів. Ідеться про те, що для їх застосування фахівці повинні мати грунтовні знання 3 економіки, фінансів, значний практичний досвід роботи у відповідній сфері діяльності.

Продовженням якісного аналізу обов'язково повинен бути кількісний аналіз ризиків. Його результати надають інформацію щодо кількісної величини окремих ризиків, а не сукупного ризику діяльності підприємства [25].

Розглянемо найпоширеніші методи оцінки ризиків підприємства.

Експертний метод вважається більш суб' єктивним, адже базується на судженнях експертів. Його доцільно використовувати при недостатній інформації, що $\epsilon$ його істотною перевагою над іншими методами оцінки ризиків підприємства. При цьому експертна оцінка найчастіше здійснюється з використанням методу «Делфі». Він базується на проведенні серії послідовних опитувань експертів без особистих дебатів між ними. Повторення процедури опитування дозволяє експертам ще раз переглянути 
свої судження, проаналізувати інформацію, надану іншими експертами. Так досягається одержання точнішої інформації. Також при використанні даного методу застосовують диференційовані оцінки, коли судженням окремих експертів надається більша вагомість. Однак при використанні методу «Делфі» потрібно досить ретельно підходити до формулювання питань анкети, щоб вони були чітко сформульовані й найбільш повно розкривали проблему. Загалом експертний метод заслуговує на увагу, але лише на початкових етапах оцінювання ризиків діяльності підприємства [26].

На підставі використання методу експертних оцінок застосовують методику Швейцарської банківської корпорації [27]. Дана методика складається 3 чотирьох етапів: визначення напрямку аналізу; збір, групування вихідних даних; визначення ступеня ризику; визначення сукупного ступеня ризику. На підставі даної методики можна зробити висновок про фінансову стійкість економіки, а отже, і про рівень ділової активності суб'єктів господарювання. А також ії перевагою є можливість вибору оптимального варіанту розвитку діяльності підприємства.

Для визначення ступеня ризику використовують методику, розроблену фірмою BERI (Німеччина) [28]. За даною методикою розраховується спеціальний індекс (на підставі опитування 100 незалежних експертів), який дає змогу оцінити ступінь ризику.

Метод аналогій. Його суть базується на оцінюванні ризиків шляхом аналізу інформації за подібними за рівнем ризику проєктах. Складнощі в застосуванні даного методу полягають у виборі аналога. Складно знайти подібний проєкт, який ще буде реалізовуватися в аналогічних умовах зовнішнього середовища. Цей метод доцільно використовувати в тих випадках, якщо підприємство нещодавно реалізувало однотипний проєкт і $є$ вся необхідна інформація щодо нього.

Аналіз доцільності витрат. Даний метод базується на різних рівнях ризику витрат за кожним напрямом діяльності. Для цього аналізується кожен елемент витрат. Залежно від фактичного стану кожного 3 них роблять висновки щодо можливої зони витрат. Таким чином, метод доцільності витрат дозволяє виявити «вузькі» місця в діяльності підприємства з позиції ризикованості [29].

Статистичний метод дозволяє оцінити ризик діяльності підприємства на основі статистичних даних за минулий період. Якщо $є$ достатньо інформації про основні ризики діяльності підприємства у минулих періодах, то можна здійснити оцінку ймовірності їх виникнення у майбутньому.

Основними показниками, які розраховуються у статистичному методі, є: математичне очікування, дисперсія, середньоквадратичне відхилення, коєфіцієнт варіації [30]. 
Математичне очікування $M(x)$ дозволяє визначити найімовірніший результат, який можна отримати у майбутньому:

$$
M(x)=\sum_{i=1}^{n} x_{i} \times p_{i},
$$

де $x_{i}-$ значення випадкової величини залежно від конкретних умов; $p_{i}-$ ймовірність можливих значень випадкової величини.

Дисперсія $D(x)$ :

$$
D(x)=\sum_{i=1}^{n} p_{i} \times\left(x_{i}-M(x)\right)^{2} .
$$

Середньоквадратичне відхилення $\sigma$ :

$$
\sigma=\sqrt{D(x)}
$$

Вище значення середньоквадратичного відхилення свідчить про вищий ризик діяльності підприємства.

Коєфіцієнт варіації $V$ :

$$
V=\frac{\sigma}{M(x)} .
$$

Коєфіцієнт варіації може мати значення від 0 до 100\%. Чим вище його значення, тим вищий ризик підприємницької діяльності.

Статистичний метод $\epsilon$ досить простий у розрахунках. За його допомогою визначають можливість настання втрат та рівень ризику, однак він потребує значної кількості вихідної інформації. Це може зумовити складнощі у його використанні. А через те, що в майбутньому можливий вплив факторів, яких не було в минулих періодах, статистичний метод не дозволяє достовірно оцінити рівень витрат у майбутньому. Крім того, не доцільно використовувати статистичний метод, якщо досліджується нове підприємство.

Метод Монте-Карло є методом імітаційного моделювання, що забезпечує моделювання випадкових величин. Даний метод передбачає, що спочатку для цільової випадкової величини генерується набір випадкових значень, які $є$ відмінними один від одного. Далі цю множину випадкових значень обробляють за допомогою методів математичної статистики.

Метод Монте-Карло передбачає чітку послідовність дій при оцінюванні ризиків. Алгоритм оцінювання передбачає такі кроки:

1. Формування прогнозної моделі.

2. Визначення ключових чинників ризику.

3. Встановлення умов кореляції між результативним показником і змінними. 
4. Вибір характеру розподілу ймовірностей.

5. Імітаційне моделювання випадкових сценаріїв реалізації.

6. Аналіз отриманих результатів за допомогою статистичної оцінки [31].

Метод Монте-Карло вважається досить точним при оцінюванні ризиків, оскільки моделювання сценаріїв здійснюється автоматично, що виключає суб'єктивні оцінки. Але даний метод вимагає значних затрат часу та інформаційних ресурсів. Переваги цього методу в оцінюванні економічної невизначеності є очевидними і незаперечними.

За результатами дослідження можна зробити такі висновки:

- традиційні інструменти оцінювання невизначеності є достатньо простими для реалізації, але забезпечують «поверхневий» результат, даючи достатньо обмежену відповідь на питання, яким був або яким $є$ вплив невизначеності на діяльність підприємства;

- «глибший», у сенсі точніший, результат забезпечується при застосовуванні новітніх інструментів аналізу, зокрема показник EVA, a також при використанні збалансованої системи показників, методу експертних оцінок, методу аналогій, при аналізі доцільності витрат тощо;

- в аналізі не доцільно обмежуватися лише одним методом, оскільки вища точність та об'єктивність результатів оцінки ризиків досягається при використанні декількох методів.

\section{תimepamypa:}

1. Frank H. Knight, Ph.D. Risk, Uncertainty and Profit. Boston and New York, Houghton Mifflin Co., The Riverside Press, 1921.

2. Kallman J. Instructors' manual, the Tools \& Techniques of Risk Management \& Insurance. National Underwriter, Cincinnati, OH, 2007.

3. Crouhy M., Galai D., Mark R. Risk Management. New York : McGraw-Hill, 2012. 390 p.

4. Mccarthy M., Flynn T. Risk From the CEO and Board Perspective: What All Managers Need to Know About Growth in a Turbulent World. New York : McGraw Hill, 2003. 256 p.

5. Розвиток економічної науки видатними науковцями з української діаспори : матеріали науково-практичної конференції (Київ, 3 квітня 2020 р.). Вищий навчальний заклад «Університет економіки та права «КРОК», 2020. $33 \mathrm{c}$.

6. Петти В., Смит А., Рикардо Д., Кейнс Дж., Фридмен М. Классика экономической мысли: Сочинения. Москва : ЭКСМО-Пресс, 2000. $753 \mathrm{c}$.

7. Рикардо Д. Сочинения: в пяти томах. Москва : Госполитиздат, 1955. T. $1.360 \mathrm{c}$. 
8. Маркс К., Энгельс Ф. Критика политической экономии. Сочинения. 2-е изд. Москва : Политиздат, 1968. Соч. 46. Ч. 1. С. 533.

9. Макконелл К. Р., Брю С. Л. Экономикс: Принципы, проблемы и політика. Москва : Республика, 1992. 799 с.

10. Leibenstein H. Allocative Efficiency and X-Efficiency. The American Economic Review. 1966. №56. P. 392-415.

11. Oxford Dictionaries. URL : https://www.lexico.com/definition/ efficiency.

12. Oxford Dictionaries. URL : https://www.lexico.com/definition/ effectiveness.

13. Друкер П. Классические работы по менеджменту. Москва : Юнайтед пресс, 2010. 224 с.

14. ДСТУ ISO 9000:2007 Системи управління якістю. Основні положення та словник термінів (ISO 9000:2005, IDT). Чинний від 200801-01. Вид. офіц. Київ : Держспоживстандарт України, 2008. 31 с.

15. Measuring Productivity : Measurement of Aggregate and Industrylevel Productivity Growth. OECD Manual. Paris : OECD, 2001. P. 126-127.

16. Андрійчук В. Г. Ефективність діяльності аграрних підприємств: теорія, методика, аналіз : монографія. Київ : КНЕУ, 2005. 292 с.

17. Любкіна О. В. Діагностика фінансової діяльності i прогнозування перспектив розвитку бізнесу на основі баготофакторної моделі рентабельності. Ефективна економіка. 2018. №3. URL : http://www.economy.nayka.com.ua/pdf/3_2018/48.pdf.

18. Лелюк О. О. Особливості аналізу ефективності використання капіталу агропромислових формувань. Вчені записки Університету «КРОК».2009. Вип. 20. Т. II. С. 217-227.

19. Кошельок Г. В., Малишко В. С. Факторний аналіз рентабельності власного капіталу. URL : http://dspace.oneu.edu.ua/jspui/bitstream.

20. Розвиток промисловості для забезпечення зростання та оновлення української економіки : Науково-аналітична доповідь / За ред. Дейнеко Л. В. ; НАН України, ДУ «Ін-т екон. та прогнозув. НАН України». Київ, 2018. 158 с. С. 15.

21. Спільник I. Аналіз економічної доданої вартості підприємства. Економічний аналіз. 2013. Вип. 12. Ч. 4. С. 70-74.

22. Rowland Z. Decomposition of EVA Equity to the Sub-operational Plans of a Company. Littera Scripta. 2016. №9(3). C. 52-65.

23. Свідерська I. М. Економічна додана вартість: теоретичні аспекти розрахунку та використання показника. Економіка та держава. 2013. №11. C. 52-54.

24. Нівен Пол Р. Діагностика збалансованої системи показників: Підтримуючи максимальну ефективність / Пер. 3 англ.; за наук. ред. М. Горського. Дніпропетровськ : Баланс Бізнес Букс, 2006. 256 с. 
25. Петрова В. Ф. Методичне забезпечення оцінки ризиків підприємства. Соціальна економіка. 2015. Вип. 50. №2. С. 148-153.

26. Пернарівський О. В., Орловська Ю. М. Використання експертних методів при оцінюванні системного ризику в банківській діяльності. Прачі Одеського політехнічного університету. 2011. Вип. 3(37). С. 52-57.

27. Клименко С. М., Дуброва О. С. Обгрунтування господарських рішень та оцінка ризиків : навч. посібник. Київ : КНЕУ, 2005. 252 с.

28. Kobrin S. J. Political Risk: A Review And Reconsideration. Journal of International Business Studies, Palgrave Macmillan. Academy of International Business. Vol. 10(1). P. 67-80.

29. Сорочак О. З., Олійник Р. В. Методи кількісного аналізу та управління проектними ризиками. URL : http:/ena.lp.edu.ua:8080/ bitstream/ntb/16669/1/411-698-699.pdf.

30. Михальчук А. В., Вербицька К. С. Підприємницький ризик: функції, методи оцінки та шляхи зниження ризику. Вісник ЖДТУ. 2015. №2(72). С. 162-168.

31. Жентичка Ю. Ю. Використання методу Монте-Карло для розрахунку фінансово-виробничого ризику. URL : http://libfor.com/ index.php?newsid=2418. 